\title{
Consumer Preferences towards FMCG in Rural Areas in Sivagangai District
}

\author{
P. Pandian
}

\begin{abstract}
Marketing in Rural territories in Republic of India isn't a great deal of created there are a few preventions inside the space of market, item style and situating valuing, circulation and advancement. Organizations got the opportunity to see country advancing in an exceedingly more extensive way not exclusively to endure and develop the organisation or venture, anyway furthermore a strategy to the occasion of the rural society. One must have a key perused of the horticultural markets in this manner on secure and see the business sectors well. The Indian quick paced ware (FMCG) business started to shape before 50 years. The FMCG part could be a foundation of the Indian economy. This part contacts each side of the life of human. This displays an astonishing shot for makers of marked product WHO will change over clients to search for marked product. India's FMCG segment makes work for very 3 million people in downstream exercises. the entire FMCG market is in path over Rs 850 billion. it's by and by developing at twofold digit rate and is anticipated to keep up a high pace of development.
\end{abstract}

Keywords : Rural Marketing, Rural Economy.

\section{INTRODUCTION}

Rural promoting might be a technique for creating, estimating, advancing, and conveying product and administrations in country territories bringing about wanted trade with provincial clients to fulfill the desires and demands, and conjointly to understand the goals of the association. Rural marketing in India isn't a great deal of created there are a few blocks inside the space of market, item style and situating, estimating, conveyance and advancement. Firms ought to see provincial advancing during a more extensive way not exclusively to endure and develop the venture, anyway conjointly a strategy to the occasion of the rural society. One must have a vital perused of the rural markets in this way on handle and see the business sectors well. The Indian quick paced merchandise (FMCG) business started to frame all through before 50 years. The FMCG segment might be a foundation of the Indian economy. This area contacts each side of the life of the human. This exhibits an inconceivable producers of marked product. World Health Organization will change over customers to look for marked product. India's FMCG part makes work for more than 3 million people in downstream exercises. the general FMCG market is in definitely more than Rs 850 billion. it's by and by developing at twofold digit

Revised Manuscript Received on December 05, 2019.

* Correspondence Author

Dr. P. Pandian*, Assistant Professor in Commerce, KCSKNC, Chennai, India. Mail id: pandian.kkdi@gmail.com rate and is anticipated to keep up a high rate.

\section{REVIEW OF LITERATURE}

Bhatia (2007) found that country India incorporates an enormous exceptional classification with forty one percent of India's group and fifty eight percent of the entire pay. The horticultural market represented $70 \%$ of restroom cleanser clients, and essentially $50 \%$ of TV sets, fans, weight cookers, bikes, clothing cleansers, cleansers, tea, salt and tooth powder. The horticultural commercial center for FMCG item was growing a great deal of snappier than the urban partner.

Mohankumar (2010) in his investigation paper uncovered the attitudinal impacts on the decision making strategy for customers in getting FMCG item in an exceedingly large area of selling place kept to Procter and Gamble company cleansers and cleansers. This content presents the predominant and wanted item consolidate strategies in FMCG classes conquering any hindrance among companies and consequently the clients. The article begins with the issue articulation pursued by importance, destinations, scope, technique, restrictions of the examination, framework of discoveries and proposals and recommendations.

\section{OBJECTIVES OF THE STUDY}

1. To study the opportunities for FMCG produced by MNCs in rural areas.

2. To review the impact of promotional and other techniques adopted by MNCs for promoting of FMCG in non urban areas.

3. To study the consumer attitude and satisfaction for MNCs' FMCG in non urban places and villages.

4. To analyze the awareness, satisfaction and priority of consumers for FMCG produced by MNCs in rural places and villages.

\section{RESEARCH METHODOLOGY}

\section{A. Research Design}

The research comprises the sample for the information gathering, calculation and understanding of the investigation. It is the general example or structure, of the examination which stipulates what data is to be gathered from which sources by what methodology. Research configuration utilized for this examination is elucidating exploration structure which is descriptive research design. 


\section{Consumer Preferences Towards FMCG in Rural Areas in Sivagangai District}

\section{B. Sampling Procedure}

Among the different districts in South Tamil Nadu, Sivagangai district is purposively opted for this study based on concentration of rural population. The data have been collected from rural respondents by using stratified random sampling method after pilot study through schedule method. The marketing and promotional strategies and their volume of transactions, opportunities and challenges for the FMCG products of Hindustan Unilever Limited, Procter and Gamble and Nestle have been collected from the retailers in rural areas.

\section{Sample Size}

Based on the response from rural consumers and retailers through pilot study, 100 rural consumers are selected for the present study.

\section{Statistical Techniques}

- Percentage analysis

- Multiple Regressions

- Chi square test

- Factor analysis method

\section{E. Data Collection:}

Both primary and secondary data was used for the study and collected from the rural consumers and secondary data from journals, websites etc.

\section{SUMMARY OF FINDINGS}

Increase in income level of family, funds availability, availability of attractive sales promotional schemes, need for comfort/ sophistication, individual values and attitudes, increasing consumer's expectations, brand loyalty, convenience in usage of the product, influence of $\mathrm{TV}$, influence of print media, influence of friends/ relatives / colleagues, awareness of new products, brand features, utility of products, product availability and credit facilities are strongly influencing the consumer's purchase method of FMCG products in non urban areas. Availability of savings, availability of additional source of income, expected risk in terms of obsolescence, dominance of senior person in family, availability of choice leading to complexity in purchase, realization of his/her ego needs, influence of road show, influence of van campaign, suppliers/ dealers are having moderate level of influence on the consumer's purchase method of FMCG items in rural areas. The influence of wall painting, company brochures and company sales force are having less influence on the consumer's purchase method of FMCG items in non urban places.

The correlation analysis shows that there square measure 10 freelance teams were extracted that account for a complete of sixty nine. 50 per cent of variations on the twenty five variables. The every of 10 factors contributes thirteen.12 per cent, 9.75 per cent, 7.99 per cent, 6.86 per cent, 6.09 per cent, 5.98 per cent, 5.75 per cent, 5.09 per cent, 4.59 per cent and four.28 per cent severally and these factors square measure classified in to convenient, packaging, affordability, exposure, values, promotions, accessibility, snug, name and complete image.

\section{CONCLUSION}

The non convenience of rural data, lesser access to finance, cultural and language barriers, lack of adequate supplying facilities, unfavourable government policies, unfavourable regulative barriers, resistance from native businessmen and disapponting law and order area unit the external barriers to increasing rural markets for fast-paced goods (FMCG) by MNCs in rural areas. The magnitude of up front investments and long gestation area unit the most important internal barriers to increasing rural markets for fast-paced goods (FMCG) by MNCs and also the cultural distinction, temperament of existing employees to figure in rural areas, skepticism regarding size and viability of rural market and lack of commitment type high management area unit the minor internal barriers to increasing rural markets for fast-paced goods (FMCG) by MNCs in rural areas.

\section{REFERENCES}

1. Bhatia, T. K. (2007). Advertising \& Marketing in Rural India: Language, Culture, and Communication. Macmillan.

2. Foxall, G. R., Oliveira-Castro, J. M., James, V. K., Yani-de-Soriano, M M., \& Sigurdsson, V. (2006). Consumer behavior analysis and social marketing: The case of environmental conservation. Behavior and social issues, 15(1), 101-125.

3. Goodstein, R. C. (1993). Category-based applications and extensions in advertising: Motivating more extensive ad processing. Journal of consumer research, 20(1), 87-99.

4. Hoyer, W. D., \& Brown, S. P. (1990). Effects of brand awareness on choice for a common, repeat-purchase product. Journal of consumer research, 17(2), 141-148.

5. Krishna, K.L, Paridhavi M., Jagruti, A.P., (2008), "Rural Consumers in India", Indian Journal of Marketing, 22(3): pp. 135-145

6. Letelier, M. F., Flores, F., \& Spinosa, C. (2003). Developing productive customers in emerging markets. California Management Review, 45(4), 77-103.

7. Mohankumar, T. P., \& Shivaraj, B. (2010). Product Mix Strategies: FMCG in Indian Market. SCMS Journal of Indian Management, 7(2).

8. Sunday, A., \& Bayode, B. (2011). Strategic Influence of Promotional Mix on Organisation Sale Turnover In The Face Of Strong Competitors Management \& Marketing Journal, 9(1).Anil Kumar S. Hagargi, (2011), "Rural Market in India: Some Opportunities and Challenges", International Journal of Exclusive Management Research, 1(1):pp.1-15.

\section{AUTHORS PROFILE}

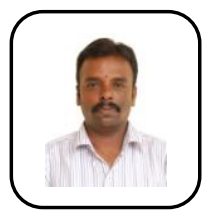

Dr.P.Pandian, M.C.S., M.Com., M.B.A., M.Phil., Ph.D is currently working as Assistant Professor in KCS Kas Nadar College of Arts and Science, Chennai - 21, with 21 years of teaching experience in various institutions with more than 20 publications and presented papers in national and international conference. 